\title{
Studies of transferrin in serum of workers exposed to organic solvents
}

\author{
S PETRÉN, O VESTERBERG \\ From the Chemistry Division, Research Department, National Board of Occupational Safety and Health, \\ S-171 84 Solna, Sweden
}

ABSTRACT Earlier studies have shown that determination of the serum concentration of differen⿳亠丷厂 forms of transferrin (isotransferrins) may be used to detect hepatic effects caused by alcohol abusete The isotransferrin variant with an isoelectric point of 5.7 has been compared with the total amourff of serum transferrin in order to study hepatic effects caused by occupational exposure to organigs solvents. Eighteen workers from a paint industry were tested before and after their holiday and compared with two different groups, a total of 60 subjects. The solvent workers had significantly higher values both before and after their holiday. This suggests that the effects on the liver cause by organic solvents are similar to those caused by alcohol abuse and that this is a long term effece The level of exposure to organic solvents was below the Swedish threshold limit values.

Serum transferrin is a protein synthesised and catabolised in the liver; its main function is iron transportation in the blood. Transferrin has many variants (isoproteins) which may be separated by isoelectric focusing (IEF). Except for differences that are genetically caused (differences in the aminoacid sequence) the main difference in isoelectric point ( $\mathrm{pI}$ ) between the variants is due to the variable number of sialic acid groups attached to the carbohydrate parts of the transferrin molecule. ${ }^{12}$ One of these variants, with a pI of $5.7\left(\operatorname{Tf}_{5.7}\right)$, has been shown to be increased after alcohol abuse. ${ }^{13}$ In the present study a similar effect is shown to follow occupational exposure to organic solvents.

\section{Subjects and methods}

Workers exposed for between one and 10 years in a paint industry plant were studied. Blood sera were obtained on two different occasions; sample A was taken in the middle of an ordinary working week and sample B on the first or second workday after holiday (the latter being at least two but usually three or four weeks). All samples were frozen at $-70^{\circ} \mathrm{C}$ within one day and were analysed within one month. The referents were blood donors (referents D) and a group of non-exposed subjects (referents $M$ ) working in the same area as the exposed workers. Samples from the

Accepted 29 September 1986 referents and exposed workers were treated and anas lysed in the same way. None of the workers or the referents reported any alcoholic problems. Table $\bar{\Phi}$ shows the composition of the groups. Interviews using a standardised form, about drug and alcohof

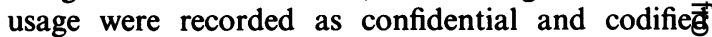
information for the exposed and referents $M$. Infor mation obtained about alcohol usage a few week before the blood sampling was regarded as reliabe due to good personal contact and cooperatiog between the workers and the interviewing nurse. Only a few used drugs at the time of the study; two used oral contraceptives and one was taking antibiotics.

Transferrin measurements were made as describeg earlier. ${ }^{4}$ After iron saturation, the transferrin with p $5.7\left(\mathrm{Tf}_{5.7}\right)$ was separated by isoelectric focusing and quantified with zone immunoelectrophoresis assay (ZIA). The total concentration of transferrin $\left(\mathrm{Tf}_{\mathrm{to}}\right.$ was also determined with ZIA. The transferrin rati $\left(\mathrm{Tf}_{\mathrm{ratio}}\right)$ was calculated as:

$$
\mathrm{Tf}_{\text {ratio }}=\mathrm{Tf}_{5.7} / \mathrm{Tf}_{\text {tot }} \times 100
$$

Environmental air sampling for solvents was cafs ried out by pumping a measured volume of a through sampling tubes containing charcoal. All the air samples, obtained during ordinary working ope ations, were taken for two to four hours in the breathing zone of the workers using personal samplers of typical production days as estimated by the health centre staff and the workers. Extraction of the chae 
coal was made with carbon disulphide before analysis by gas chromatography. Wilcoxon's rank test and Wilcoxon's signed rank test were used for statistical evaluations. ${ }^{5}$

\section{Results}

The results of the air analysis are presented in table 2 . The values were below the Swedish threshold limit values in force when this study was performed (1984).

Table 1 shows the total $\mathrm{Tf}$ values and the $\mathrm{Tf}_{\text {ratios }}$ for the different groups. The total amount of Tf was well within the normal range for all four groups. There was no difference in the $\mathrm{Tf}_{\text {ratios }}$ between the two referent groups but with the exposed, a statistically significant increase was found at the $95 \%$ probability level (table 3). Owing to the reliability of the alcohol usage records we do not think that this was due to a different use of alcohol. On the other hand, statistical analysis showed no significant difference between the exposed workers on a group basis before and after vacation (table 3 ). The figure illustrates the difference between referents $M$ and the exposed group before and after the holiday. The individual with the high $\mathrm{Tf}_{\text {ratio }}$ after holiday admitted a high alcoholic intake during the holiday and up to the day when sample B

Table 1 Age, sex, and transferrin data of subjects. Tf tot is mean value of total serum transferrin. $T f_{\text {ratio }}$ is the quotient between the concentrations of transferrin with isoelectric point 5.7 and $T f_{t o t}$ and expressed as a percentage. Referents $D$ and $M$ are described in the text. Exposed $A$ and $B$ refers to exposed workers sampled before and after the holiday respectively

\begin{tabular}{|c|c|c|c|c|c|c|c|c|c|}
\hline \multirow[b]{2}{*}{ Group } & & \multirow[b]{2}{*}{$N o$} & \multirow[b]{2}{*}{ Women } & \multirow[b]{2}{*}{ Men } & \multirow{2}{*}{$\begin{array}{l}\text { Age range } \\
\text { (years) }\end{array}$} & \multirow{2}{*}{$\begin{array}{l}T f_{\text {total }} \\
(g / l)\end{array}$} & \multicolumn{3}{|l|}{$T f_{\text {ratio }}$} \\
\hline & & & & & & & Mean & $S D$ & Range \\
\hline $\begin{array}{l}\text { Referents } \\
\text { Referents } \\
\text { Exposed } \\
\text { Exposed }\end{array}$ & $\begin{array}{l}\mathbf{D} \\
\mathbf{M} \\
\mathbf{A} \\
\mathbf{B}\end{array}$ & $\begin{array}{l}26 \\
17 \\
14 \\
12\end{array}$ & $\begin{array}{r}13 \\
8 \\
4 \\
4\end{array}$ & $\begin{array}{r}13 \\
9 \\
10 \\
8\end{array}$ & $\begin{array}{l}23-65 \\
23-61 \\
20-63 \\
27-63\end{array}$ & $\begin{array}{l}2 \cdot 22 \\
2 \cdot 31 \\
2 \cdot 24 \\
2 \cdot 06\end{array}$ & $\begin{array}{l}1 \cdot 84 \\
2 \cdot 18 \\
2 \cdot 71 \\
2 \cdot 84\end{array}$ & $\begin{array}{l}0.84 \\
0.36 \\
0.70 \\
0.98\end{array}$ & $\begin{array}{l}0 \cdot 7-4 \cdot 1 \\
1 \cdot 6-2 \cdot 9 \\
1 \cdot 7-3 \cdot 7 \\
1 \cdot 6-5 \cdot 0\end{array}$ \\
\hline
\end{tabular}

Table 2 Results of analysis of air samples taken in the breathing zone of each worker. The hygienic effect is obtained by determining the quotient of the calculated average air concentration and the corresponding threshold limit value for each substance adding all quotients. All values are given in $\mathrm{mg} / \mathrm{m}^{3}$

\begin{tabular}{|c|c|c|c|c|c|c|c|c|}
\hline $\begin{array}{l}\text { Sample } \\
\text { No }\end{array}$ & $\begin{array}{l}\text { White } \\
\text { spirit }\end{array}$ & Xylene & Toluene & Ethylacetate & Ethanol & Butylacetate & $\begin{array}{l}\text { Ethylglycol- } \\
\text { acetate }\end{array}$ & $\begin{array}{l}\text { Hygienic } \\
\text { effect }\end{array}$ \\
\hline $\begin{array}{l}1 \\
2 \\
3 \\
4 \\
5 \\
6 \\
7 \\
8 \\
9 \\
10 \\
11 \\
12 \\
13 \\
14 \\
15 \\
16 \\
17 \\
18 \\
19 \\
20 \\
21 \\
22\end{array}$ & $\begin{array}{r}137 \\
247 \\
60 \\
66 \\
179 \\
70 \\
42 \\
49 \\
157 \\
164 \\
69 \\
233 \\
42 \\
25 \\
39 \\
90 \\
43 \\
27 \\
49 \\
135 \\
30 \\
44\end{array}$ & $\begin{array}{c}47 \\
70 \\
26 \\
20 \\
36 \\
21 \\
51 \\
89 \\
21 \\
24 \\
16 \\
42 \\
16 \\
-70 \\
192 \\
- \\
22 \\
40 \\
20 \\
22\end{array}$ & $\begin{array}{l}- \\
- \\
- \\
- \\
- \\
27 \\
- \\
- \\
- \\
- \\
- \\
- \\
- \\
- \\
34 \\
- \\
- \\
-\end{array}$ & $\begin{array}{c}- \\
\overline{103} \\
24 \\
- \\
\overline{114} \\
- \\
- \\
- \\
- \\
- \\
23 \\
-14 \\
26 \\
32 \\
22 \\
55 \\
155 \\
75\end{array}$ & $\begin{array}{l}- \\
- \\
- \\
- \\
- \\
10 \\
30 \\
- \\
- \\
18 \\
- \\
- \\
- \\
49 \\
- \\
- \\
615\end{array}$ & $\begin{array}{l}- \\
-13 \\
- \\
- \\
- \\
- \\
- \\
- \\
- \\
- \\
- \\
- \\
- \\
- \\
- \\
- \\
-\end{array}$ & $\begin{array}{l}- \\
- \\
- \\
- \\
- \\
13 \\
19 \\
- \\
- \\
- \\
- \\
- \\
- \\
- \\
- \\
- \\
-\end{array}$ & $\begin{array}{l}0.41 \\
0.69 \\
0.36 \\
0.22 \\
0.46 \\
0.20 \\
0.36 \\
0.41 \\
0.37 \\
0.40 \\
0.19 \\
0.60 \\
0.16 \\
0.05 \\
0.30 \\
0.77 \\
0.94 \\
0.16 \\
0.19 \\
0.46 \\
0.34 \\
0.48\end{array}$ \\
\hline $\begin{array}{l}\text { Threshold } \\
\text { limit value }\end{array}$ & 500 & 350 & 350 & 700 & 1900 & 700 & 500 & \\
\hline
\end{tabular}

Table 3 Statistical comparison of the groups. The first two values are based on Wilcoxon's rank test and the last on Wilcoxon's signed rank test. A 95\% level of significance was used

\begin{tabular}{llll}
\hline Groups & Obtained value & Limit value & Conclusion \\
\hline Referents M $v$ referents D & $\mathrm{z}=1.93$ & $\mathrm{z}_{0.975}=1.96$ & No difference \\
Exposed A v referents M & $\mathrm{z}=2.01$ & $\mathrm{z}_{0.975}=1.96$ & Difference \\
Exposed A $v$ exposed B & $\mathrm{R}=-20.5$ & $5 \%=11$ & No difference \\
\hline
\end{tabular}




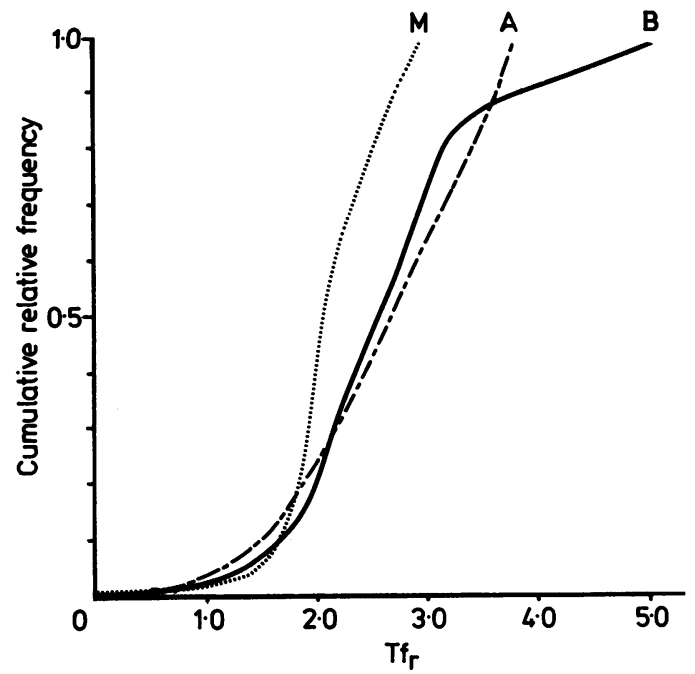

Cumulative relative frequency of differences in $T f_{\text {ratio }}\left(T f_{r}\right)$ between non-exposed group $(M)$ and exposed workers before $(A)$ and after holiday $(B)$. Single high value in group $B$ is discussed in text.

was taken. The others did not report an appreciably higher alcohol consumption during their holidays than before sample A was taken. The two referent groups did not differ statistically. The group from the health centre (M) has a slightly higher $\mathrm{Tf}_{\text {ratio }}$ mean value than the blood donor group (D). We cannot explain this by, for example, known differences in alcoholic consumption between the two groups.

\section{Discussion}

Raised $\mathrm{Tf}_{\text {ratios }}$ may indicate that the liver does not function normally. It is not known if this is a primary effect on membrane function or due to secondary cellular influences.

The $\mathbf{T f}_{\text {ratio }}$ is believed to be influenced by the liver cell membrane function. Our hypothesis is based on the fact that a high $\mathrm{Tf}_{\text {ratio }}$ often results in a raised concentration of $\mathrm{Tf}_{5.7}$ that has a lowered content of sialic acid compared with the main Tf component. The sialic acid groups of transferrin are believed to be split off the protein molecules in the blood towards the end of their lifetime. Human transferrin is reported to have a biological half life of about nine days. ${ }^{6}$ A low content of sialic acid on the transferrin molecule has been proposed as a signal to the hepatic cell that the molecule should be eliminated from the bloodstream. ${ }^{78}$ This is analogous with findings for other proteins such as orosomucoid. ${ }^{9}$

We have shown that proved alcoholics generally have much increased $\mathrm{Tf}_{\text {ratio }}$ values with a group mean value more than twice as high as the occupationally exposed workers of this study. ${ }^{3}$ Alcoholics when in hospital for more than a week usually showed decreasing $\mathrm{Tf}_{\text {ratios. }}$ This has been found to be duछ mostly to increasing values of $\mathrm{Tf}_{\text {tot }}$ rather than to decreasing $\mathrm{Tf}_{5.7}(\mathrm{~S}$ Petrén, O Vesterberg, unpublishe $\overline{\bar{\alpha}}$ observation). For the solvent exposed subjects of this study, $\mathrm{Tf}_{\text {tot }}$ was, on average, $10 \%$ higher than for the alcoholics and the values did not change significantly after their holiday. The $\operatorname{Tf}_{5.7}$ was lower in the alcohol $\Phi$ ics and did not change either. A small proportion of the alcoholics who were followed up for 21 days, how? ever, did not obtain $\mathrm{Tf}_{\text {ratio }}$ values within the norma $\vec{\Phi}$ range (below 3.0) during the study. ${ }^{3}$ The presen $E$ study indicates that long term exposure to organife solvents may have an effect on the liver similar to thao of alcohol abuse. The effect (higher $\mathbf{T f}_{\text {ratios }}$ ) is less pro 3 nounced, however, than after alcohol abuse. The exposure to organic solvents in the plant where the studies were carried out has decreased during the pasit years due to better education of the workstaff in wayg of avoiding excessive exposure and much improved air ventilation. The effects observed on the $\mathrm{Tf}_{\text {ratio }}$ may be caused by higher exposure in the years preceding this study. Exposure to aromatic solvents-for exame ple, toluene-was higher some years ago but has since decreased.

This work was supported by grants from the Swedish National Board of Occupational Safety and Healtho We are much obliged for the good help and coopers ation with the Ulvsunda Health Centre and its pere sonnel. We are also grateful to Mr B Dynesius foD skilful analysis of air samples and linguistic revisiom by Dr M Oxenburough.

\section{References}

1 Stibler H, Borg S. Evidence of a reduced sialic acid content iळ serum transferrin in male alcoholics. Alcoholism and Clinica Experimental Research 1981;5:545-9.

2 Putnam FW. The structure of the plasma proteins. In: Putnan FW, ed. The plasma proteins. Vol IV. Orlando: Academic Press. Inc, 1984:46-166.

3 Vesterberg O, Petrén S, Schmidt D. Increased concentrations of transferrin variant after alcohol abuse. Clin Chim Actg 1984;141:33-9.

4 Petrén S, Vesterberg O. Quantification of a protein variant aftey focusing in agarose gel using carbamylated myoglobin as a co를. oured marker. Electrophoresis 1984;5:26-9.

5 Box GEP, Hunter WG, Hunter JS. Statistics for experimenter fo New York: John Wiley \& Sons, 1978.

6 Schultze HE, Heremans JF. Turnover of the plasma proteins. In Schultze HE, Heremans JF, eds. Molecular biology of humañ proteins. Vol 1. Amsterdam: Elsevier, 1966:450-517.

7 Tavill AS. Hepatic protein metabolism: basic and applied bi@ chemical aspects. In: Arias IM, Frenkel M, Nilson JHP, eden The liver annual 2/1982. Amsterdam: Excerpta Medica 1982:28-61.

8 Schachter H. Glycoproteins: their structure, biosynthesis and possible clinical implications. Clin Biochem 1984;17:3-14.

9 Ashwell G, Morell A. The role of surface carbohydrates in the hepatic recognition and transport of circulating glyco proteins Adv Enzymol 1974;41:99-128. 